\title{
Article \\ Techno-Economic Feasibility of In Situ Vegetable Residue Return in the Chinese Solar Greenhouse
}

\author{
Xiaoxuan Wei ${ }^{1}$, Yansu Li ${ }^{1}$, Xiaoguang Fan ${ }^{2}$, Chaoxing He ${ }^{1}$, Yan Yan ${ }^{1}$, Mintao Sun ${ }^{1}$, Chaowu Ding ${ }^{2}$, Jun Wang ${ }^{1, *}$ \\ and Xianchang $\mathrm{Yu}^{1, *}$ \\ 1 Institute of Vegetables and Flowers, Chinese Academy of Agricultural Sciences, Beijing 100081, China; \\ weixiaoxuan0411@163.com (X.W.); liyansu@caas.cn (Y.L.); hechaoxing@caas.cn (C.H.); \\ yanyan@caas.cn (Y.Y.); sunmintao@caas.cn (M.S.) \\ 2 Weifang Ruixuan Agricultural Technology Co., Ltd., Shouguang 262700, China; fxg1000@126.com (X.F.); \\ dc2015927@163.com (C.D.) \\ * Correspondence: wangjun01@caas.cn (J.W.); yuxianchang@caas.cn (X.Y.); \\ Tel.: +86-10-82109507 (J.W.); +86-10-82109580 (X.Y.)
}

check for updates

Citation: Wei, X.; Li, Y.; Fan, X.; He, C.; Yan, Y.; Sun, M.; Ding, C.; Wang, J.; $\mathrm{Yu}, \mathrm{X}$. Techno-Economic Feasibility of In Situ Vegetable Residue Return in the Chinese Solar Greenhouse. Agronomy 2021, 11, 1828. https:// doi.org/10.3390/agronomy11091828

Academic Editors: Syed

Tahir Ata-Ul-Karim,

Saadatullah Malghani and Muhammad Ishaq Asif Rehmani

Received: 12 August 2021

Accepted: 8 September 2021

Published: 13 September 2021

Publisher's Note: MDPI stays neutral with regard to jurisdictional claims in published maps and institutional affiliations.

Copyright: (c) 2021 by the authors. Licensee MDPI, Basel, Switzerland This article is an open access article distributed under the terms and conditions of the Creative Commons Attribution (CC BY) license (https:// creativecommons.org/licenses/by/ $4.0 /)$
Abstract: The tremendous scale of protected vegetable cultivation incidentally produces considerable vegetable residue, which refers to the remaining parts of plants after the final harvest. The low use rate of vegetable residue results in nutrient waste and environmental pressure in China. In this study, we put forward vegetable residue directly returned to the soil and investigated its feasibility. Residue return was steadily conducted 5 times in a Chinese solar greenhouse with the cucumber-tomato rotation pattern. Results showed that residue return increased the soil alkali-hydrolysed nitrogen and available potassium contents by $4.97-26.22 \%$ and $9.31-21.92 \%$, respectively, along with slightly reduced soil $\mathrm{pH}$ and bulk density by $1.00-5.39 \%$ and $6.72-11.81 \%$, respectively. Gemmatimonadetes, Firmicutes, Acidobacteria, Basidiomycota, and Mortierellomycota were the major phyla with noticeable changes when residue return was conducted 5 times. Fruit yield began to obtain remarkable increase by 5.81-9.26 $\mathrm{t} \cdot \mathrm{ha}^{-1}$ after residue return was conducted 3 times, bringing about additional profits of 5382.0-8519.2 USD ha $^{-1}$. Residue return could cut down the disposal expense of vegetable residues by 480.89 USD $^{-1} \mathrm{ha}^{-1}$. Moreover, residue return could supplement nutrients to soil, potentially contributing to reducing chemical fertilizer inputs. In conclusion, in situ vegetable residue return could be considered to be a feasible and sustainable use technique for vegetable residues in the Chinese solar greenhouse.

Keywords: vegetable residues; physicochemical characteristics; microbial communities; yield; feasibility

\section{Introduction}

With rapid economic development and population growth, the area of protected vegetable cultivation in China has dramatically increased, approaching 3.92 million ha in 2016. The enormous cultivated scale incidentally produces considerable vegetable residues, which are the remaining parts of vegetable plants after the final harvest. In view of the reported total vegetable residues in China [1] and the proportion of vegetable yield in protected facilities among the total vegetable production [2], it is estimated that vegetable residues from protected vegetable cultivation amounted to almost 73.78 million tons in 2016. Based on the reported contents of organic matter (approximately 70\%, dry basis), nitrogen ( $\mathrm{N}$, approximately $3.45 \%$, dry basis), phosphorus ( $\mathrm{P}$, approximately $0.84 \%$, dry basis), and potassium (K, approximately $2.46 \%$, dry basis) [1], vegetable residues contain approximately 5.16 million tons of organic matter, 0.25 million tons of $\mathrm{N}, 0.06$ million tons of $\mathrm{P}$, and 0.18 million tons of $\mathrm{K}$. Considering the high nutrient level, vegetable residues could be reused as a nutritional resource.

Currently, the main use methods for vegetable residues are anaerobic digestion [3] and composting [4]. The former converts vegetable residues into ethanol and biogas [5]. Due to 
the complexity of the process of anaerobic digestion and its equipment requirements, it has not been widely applied in the process of vegetable residue use [6]. Composting is considered an economic technique to help increase vegetable residue use [7]. Returning compost to the soil can improve the soil physicochemical and microbiological characteristics [8]. However, the release of $\mathrm{CO}_{2}$ and $\mathrm{NH}_{3}$ during the composting process resulted in severe losses of $\mathrm{N}$ and carbon (C) [9]. Additionally, the application of the immature compost has adverse effects on seed germination, root elongation, and plant growth [10]. Moreover, the unfavourable aspects of composting (such as transportation, site, labour requirement, and bad smell) have made it unpopular. Therefore, most vegetable residues are simply and carelessly thrown away or incinerated in China; this results in groundwater pollution, greenhouse gas emissions, and detrimental pathogen breeding [11]. Improper disposal is not only a severe waste of resources but also a great challenge to the environmental carrying capacity. Hence, the exploration of the feasible and economic techniques for the use of vegetable residue is urgently needed.

Vegetable residues are rich in nutrient and organic matter, such as crop straw. Crop straw return could increase soil fertility and reduce chemical fertilizer input. Additionally, crop straw return is an efficient practice to sequestrate soil carbon, which could mitigate climate change [12]. In addition, crop straw could also mitigate environment pollution by reducing straw-burning activities [13]. Hence, crop straw return has been verified as a techno-economic technology. However, the research and application of vegetable residue return is always neglected due to its characteristics, such as high water content, low $\mathrm{C} / \mathrm{N}$ ratio, and, most importantly, the possibility of carrying detrimental pathogens [14]. Therefore, the effects of vegetable residue return on soil, climate, and the environment are not clear. Recently, the risk of carrying detrimental pathogens have been markedly reduced by effective preventive measures coping with diseases and insect pests during the whole cultivation process. Hence, we put forward in situ vegetable residue return, and conducted in situ vegetable residue return in the typical Chinese solar greenhouse.

In China, tomato and cucumber are the main vegetables produced in protected cultivation, and their cultivation areas are 0.78 and 0.58 million ha in 2016, respectively [15]. The cucumber-tomato rotation cultivation pattern is commonly adopted to reduce the adverse effects of continuous cropping on soil quality. Hence, this study was designed to investigate the effects of in situ vegetable residue return on soil physicochemical characteristics, soil microbial communities, and vegetable yield with the cucumber-tomato rotation cultivation pattern. Our results will provide a better understanding of the technical feasibility of the application of in situ vegetable residue return in the Chinese solar greenhouse.

\section{Materials and Methods}

\subsection{Experimental Site Description}

The experiment was conducted from 2017 to 2020 at Shinong Farm $\left(36^{\circ} 55^{\prime} \mathrm{N}, 118^{\circ} 45^{\prime}\right.$

E) in Shouguang city, Shandong province, China. The length and span of the east-west greenhouse was $62 \mathrm{~m}$ and $10 \mathrm{~m}$, respectively. Prior to the experiment, the physicochemical characteristics of the soil in the $0-20 \mathrm{~cm}$ soil layer and the initial vegetable residues are shown in Table 1.

Table 1. The soil physicochemical characteristics.

\begin{tabular}{|c|c|c|c|c|c|c|c|c|c|c|}
\hline Samplings & $\mathrm{pH}$ & $\begin{array}{c}\mathrm{TC} \\
\left(\mathrm{g} \cdot \mathrm{kg}^{-1}\right)\end{array}$ & $\begin{array}{c}\mathrm{TN} \\
\left(\mathrm{g} \cdot \mathrm{kg}^{-1}\right)\end{array}$ & $\mathrm{C} / \mathrm{N}$ & $\begin{array}{c}\mathrm{TP} \\
\left(\mathrm{g} \cdot \mathrm{kg}^{-1}\right)\end{array}$ & $\begin{array}{c}\text { TK } \\
\left(\mathrm{g} \cdot \mathrm{kg}^{-1}\right)\end{array}$ & $\begin{array}{c}\mathrm{AN} \\
\left(\mathrm{mg} \cdot \mathrm{kg}^{-1}\right)\end{array}$ & $\begin{array}{c}\mathrm{AP} \\
\left(\mathrm{mg} \cdot \mathrm{kg}^{-1}\right)\end{array}$ & $\begin{array}{c}\mathrm{AK} \\
\left(\mathrm{mg} \cdot \mathrm{kg}^{-1}\right)\end{array}$ & $\begin{array}{c}\text { Dry Weight } \\
\left(\mathrm{kg} \cdot \mathrm{ha}^{-1}\right)\end{array}$ \\
\hline Soil & 7.01 & 20.28 & 2.25 & 9.05 & 1.53 & 18.74 & 208.06 & 36.35 & 428.46 & - \\
\hline Residues & - & 286.41 & 24.12 & 11.99 & 3.52 & 16.29 & - & - & - & 1955.84 \\
\hline
\end{tabular}

TC, total carbon; TN, total nitrogen; C/N, the ratio of TC to TN; TP, total phosphorus; TK, total potassium; AN, alkali-hydrolysed nitrogen; AP, available phosphorus; AK, available potassium. 


\subsection{Experimental Design}

The non-vegetable residue return treatment $(\mathrm{CK})$ and vegetable residue return treatment $(R)$ were set up. After the final harvest of each cultivation, vegetable residues obtained in CK were removed from the greenhouse. Vegetable residues in $\mathrm{R}$ were crushed to less than $3 \mathrm{~cm}$ fragments and directly returned to the soil, whereafter sufficient water was irrigated to the soil in both treatments, and then the greenhouse was sealed. In winter, the steps of irrigating and sealing the greenhouse were omitted. The greenhouse began to ventilate before transplanting. After 7 days, the seedlings with two true leaves were transplanted. Other management measures of the vegetables in the two treatments remained the same.

Based on the cucumber-tomato rotation cultivation pattern, in situ vegetable residue return was conducted 5 times in $\mathrm{R}$ in the greenhouse. The cultivated vegetables were in order as follows: cucumber, tomato, cucumber, tomato, and cucumber. The varieties of cucumber and tomato were 'Biyu' and 'Chulian', respectively. Plant densities of cucumber and tomato were $3.97 \mathrm{plant} \cdot \mathrm{m}^{-2}$ and $2.65 \mathrm{plant} \cdot \mathrm{m}^{-2}$, respectively. According to the typical occurrence frequency of insect pests and diseases in the greenhouse, a series of precautionary measures were taken during cultivation (Table S1).

\subsection{Soil Physicochemical Characteristics}

Soil samples were taken at the post-returning stage (post, at the beginning of transplanting) and the pre-returning stage (pre, at the end of final harvest). Five random soil cores $(6 \mathrm{~cm}$ in diameter) were taken in the $0-20 \mathrm{~cm}$ soil layer along with an "S" shaped transect, then mixed thoroughly as a sample. Each treatment had three biological repetitions at each stage. Soil samples were subsequently sieved $(2 \mathrm{~mm})$ and then separated into two parts: one part was frozen at $-80^{\circ} \mathrm{C}$ for DNA extraction, and the other part was air-dried for the determination of physicochemical characteristics.

$\mathrm{pH}$ was measured in a 1:5 $(w / v)$ deionized water extract using a compound electrode (PB-10, Sartorious, Germany). Bulk density was measured with the cutting ring method [16]. The alkali-hydrolysed nitrogen (AN) content was determined by the alkali diffusion method [17]. The available phosphorus (AP) and available potassium (AK) contents were determined by ICP-AES (ICP6300, Thermo, USA) [18]. The total phosphorus (TP) and total potassium (TK) contents were measured by ICP-AES (ICP6300, Thermo, USA) according to Hao et al. (2018) [19]. The total carbon (TC) and total nitrogen (TN) contents were determined using an element analyser (Vario Macro, Elementar Analysensysteme $\mathrm{GmbH}$, Germany).

\subsection{Soil Microbial Communities}

The effect of continuous residues return on soil microbial communities was investigated at the $5^{\text {th }}$ post-returning stage and the $6^{\text {th }}$ pre-returning stage. The genomic DNA of each soil sample was extracted using a PowerSoil DNA Isolation Kit (MoBio, Carlsbad, CA, USA) according to the manufacturer's instructions. All extracted DNAs were preserved at $-80^{\circ} \mathrm{C}$ for further sequencing on the Illumina MiSeq platform (Illumina Inc., San Diego, CA, USA). The V3-V4 hypervariable region of the bacterial 16S rDNA genes and the ITS region of the fungal $18 \mathrm{~S}$ rDNA genes were subjected to high-throughput sequencing. According to the manufacturer's recommendations, the V3-V4 region was amplified using 338F (5'-ACTCCTACGGGAGGCAGCAG-3') and 806R (5'-GACTACHVGGGTWTCTAAT-3') primers [20]. The ITS region was amplified using ITS1-F (5'-CTTGGTCATTTAGAGGAAGT$\left.3^{\prime}\right)$ and ITS2 (5'-TGCGTTCTTCATCGATGC-3') primers [21]. The unique sequence set was classified into operational taxonomic units (OTUs) at a threshold of $97 \%$ identity using UPARSE [22].

\subsection{Fruit Yield and Physicochemical Characteristics of Vegetable Residues}

Fruit yield was counted during the cultivation process. Vegetable residues in each treatment were randomly collected at the pre-returning stage. The dry weight of each 
sample was measured by an electronic balance after the residues were dried at $105{ }^{\circ} \mathrm{C}$ for $15 \mathrm{~min}$ and then at $75^{\circ} \mathrm{C}$ to a constant weight. The dry residues were then ground for the determination of their physicochemical characteristics. The TC and TN contents of vegetable residues were determined using an element analyser (Vario Macro, Elementar Analysensysteme $\mathrm{GmbH}$, Germany). The TP and TK contents of vegetable residues were determined by ICP-AES (ICP6300, Thermo Fisher Scientific, USA) according to Gao et al. (2018) [23].

\subsection{Statistical Analysis}

Statistically significant differences between CK and $\mathrm{R}$ at each stage were analysed using $t$-test at the $p<0.05$ level with IBM SPSS 19.0. The relationships between soil physicochemical characteristics and soil microbial communities were analysed using redundancy analysis (RDA). CANOCO 5.0 software was used to extract the physicochemical characteristics which had the most decisive influence on microbial communities.

\section{Results and Discussion}

\subsection{Vegetable Residue Return Improved Soil Physicochemical Characteristics}

In situ vegetable residue return led to the significant variations in the soil physicochemical characteristics as shown in Table 2. The soil TC and TN contents and the soil $\mathrm{C} / \mathrm{N}$ ratio cannot only be used to evaluate the soil quality but also reflect the comprehensive effect of $\mathrm{C}$ and $\mathrm{N}$ cycles [24]. Residue return increased the soil TN and AN content by $4.98-52.57 \%$ and $4.97-26.22 \%$, respectively, compared with CK (Table 2). The lower C/N ratio of vegetable residues and the increased soil TN content resulted in a decreased soil C/N ratio (Table 2), accelerating the release of $\mathrm{N}$ from the soil as well as the mineralization of soil organic $N$ [25]. In addition, residue return increased the soil AK content by $9.31-21.92 \%$ (Table 2). K, which exists in the ionic form in plants, can be released to soil and be reused after crop straw return [26]. Except for the K provided directly by the decomposition of vegetable residues, the increased soil AK content could also be attributed to the decreased soil $\mathrm{pH}$ (Table 2), which might accelerate the transformation of mineral $\mathrm{K}$ to AK through acidolysis [27]. Residue return increased soil TP content at the $1^{\text {st }}$ post-returning stage and the $6^{\text {th }}$ pre-returning stage by $10.22 \%$ and $6.99 \%$, respectively. In addition, residue return increased soil AP content at the $2^{\text {nd }}$ pre-returning stage, $3^{\text {rd }}$ and $4^{\text {th }}$ post-returning stages by $14.33 \%, 27.00 \%$, and $4.80 \%$, respectively.

Residue return decreased soil $\mathrm{pH}$ by $1.00-5.39 \%$, which was partly due to the organic matter decomposition producing organic and inorganic acids [28,29]. Increased soil TN and AN content could also lead to decreased soil $\mathrm{pH}$ [30]. Meanwhile, residue return reduced bulk density by $6.72-11.81 \%$, consistent with the phenomenon observed under the situation of crop straw return [31]. A decrease in bulk density can promote root growth, leading to an increase in nutrient absorption and the promotion of plant growth [32]. 
Table 2. The soil physicochemical characteristics.

\begin{tabular}{|c|c|c|c|c|c|c|c|c|c|c|c|}
\hline Sampling Times & Treatments & $\mathrm{pH}$ & $\begin{array}{l}\text { Bulk Density } \\
\left(\mathrm{g} \cdot \mathrm{cm}^{-3}\right)\end{array}$ & $\begin{array}{c}\mathrm{TC} \\
\left(\mathrm{g} \cdot \mathrm{kg}^{-1}\right)\end{array}$ & $\begin{array}{c}\text { TN } \\
\left(\mathrm{g} \cdot \mathrm{kg}^{-1}\right)\end{array}$ & $\mathbf{C} / \mathbf{N}$ & $\begin{array}{c}\mathrm{TP} \\
\left(\mathrm{g} \cdot \mathrm{kg}^{-1}\right)\end{array}$ & $\begin{array}{c}\text { TK } \\
\left(\mathrm{g} \cdot \mathrm{kg}^{-1}\right)\end{array}$ & $\begin{array}{c}\mathrm{AN} \\
\left(\mathrm{mg} \cdot \mathrm{kg}^{-1}\right)\end{array}$ & $\begin{array}{c}\mathrm{AP} \\
\left(\mathrm{mg} \cdot \mathrm{kg}^{-1}\right)\end{array}$ & $\begin{array}{c}\mathrm{AK} \\
\left(\mathrm{mg} \cdot \mathrm{kg}^{-1}\right)\end{array}$ \\
\hline \multirow{2}{*}{$1^{\text {st }}$ post $(2017.09 .01)$} & CK & 7.12 & 0.96 & 23.16 & 3.50 & 6.65 & 1.86 & 20.84 & 218.75 & 17.01 & 514.76 \\
\hline & $\mathrm{R}$ & $6.86^{*}$ & 0.92 & $29.52 *$ & $5.34 *$ & $5.55 *$ & $2.05 *$ & 20.93 & 271.25 * & 16.48 & $606.73 *$ \\
\hline \multirow{2}{*}{$2^{\text {nd }}$ pre $(2017.12 .21)$} & CK & 7.23 & 1.25 & 26.43 & 2.99 & 8.87 & 2.52 & 20.62 & 175.00 & 39.36 & 457.98 \\
\hline & $\mathrm{R}$ & $6.84^{*}$ & $1.13 *$ & 25.06 & 3.15 & $7.99 *$ & 2.42 & 20.66 & 201.25 * & $45.00 *$ & $536.73 *$ \\
\hline \multirow{2}{*}{$2^{\text {nd }}$ post (2018.02.02) } & CK & 7.11 & 1.11 & 24.00 & 3.28 & 7.32 & 2.52 & 22.57 & 180.83 & 43.71 & 637.14 \\
\hline & $\mathrm{R}$ & $6.91 *$ & 1.16 & 23.66 & $3.64 *$ & $6.50 *$ & 2.48 & 22.40 & $221.67 *$ & 40.12 & $737.17 *$ \\
\hline \multirow{2}{*}{$3^{\text {rd }}$ pre (2018.07.26) } & CK & 7.44 & 1.31 & 15.18 & 1.97 & 7.70 & 2.46 & 21.45 & 151.67 & 44.66 & 411.43 \\
\hline & $\mathrm{R}$ & $7.17 *$ & $1.18 *$ & 15.65 & 2.16 & $7.26^{*}$ & 2.47 & 20.08 & $186.67 *$ & 45.08 & $487.19 *$ \\
\hline \multirow{2}{*}{$3^{\text {rd }}$ post (2018.11.02) } & CK & 7.32 & 1.06 & 16.41 & 2.46 & 6.68 & 2.78 & 22.58 & 134.33 & 23.52 & 693.75 \\
\hline & $\mathrm{R}$ & $6.97 *$ & $0.94 *$ & 16.10 & 2.58 & $6.24 *$ & 2.63 & 22.02 & $143.87 *$ & $29.87^{*}$ & $767.65^{*}$ \\
\hline \multirow{2}{*}{$4^{\text {th }}$ pre $(2019.07 .15)$} & CK & 7.72 & 1.18 & 16.88 & 2.01 & 8.42 & 2.78 & 21.19 & 129.89 & 31.37 & 582.58 \\
\hline & $\mathrm{R}$ & $7.64^{*}$ & $1.08^{*}$ & 16.89 & 2.11 * & 8.01 & $2.46^{*}$ & 20.23 * & 136.34 * & 30.25 & $638.08^{*}$ \\
\hline \multirow{2}{*}{$4^{\text {th }}$ post $(2019.09 .01)$} & CK & 7.63 & 1.21 & 17.28 & 2.12 & 8.17 & 2.66 & 20.74 & 118.99 & 36.90 & 724.62 \\
\hline & $\mathrm{R}$ & $7.5^{*}$ & $1.11 *$ & $20.80 *$ & 2.41 & 8.71 & 2.79 & $20.11^{*}$ & 148.22 * & $38.67 *$ & $883.43^{*}$ \\
\hline $5^{\text {th }}$ pre $(2020.07 .15)$ & $\mathrm{R}$ & $7.96^{*}$ & $1.12 *$ & 19.21 * & 2.17 & 8.84 & 2.75 & $16.80 *$ & $170.06^{*}$ & 35.74 & $435.55 *$ \\
\hline \multirow{2}{*}{$5^{\text {th }}$ post $(2020.09 .01)$} & CK & 7.88 & 1.18 & 18.92 & 2.48 & 7.63 & 2.89 & 17.32 & 103.35 & 43.55 & 769.95 \\
\hline & $\mathrm{R}$ & $7.72 *$ & 1.06 & 18.73 & 2.64 * & 7.08 & 2.64 & 17.75 * & 115.75 * & 44.29 & $847.90 *$ \\
\hline \multirow{2}{*}{$6^{\text {th }}$ pre $(2020.12 .21)$} & CK & 8.08 & 1.19 & 19.23 & 2.01 & 9.57 & 2.54 & 18.04 & 90.09 & 43.91 & 605.95 \\
\hline & $\mathrm{R}$ & 8.01 * & $1.11 *$ & 18.62 & $2.18 *$ & 8.53 * & 2.71 * & 18.19 & 101.63 * & 43.00 & 662.35 * \\
\hline
\end{tabular}

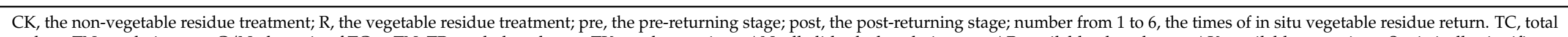

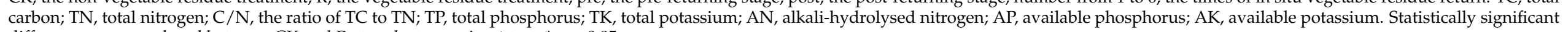
differences were analysed between $\mathrm{CK}$ and $\mathrm{R}$ at each stage using $t$-test. ${ }^{*}, p<0.05$. 


\subsection{Changes in Microbial Communities}

3.2.1. The Alpha Diversity of the Microbial Communities Affected by Vegetable Residue Return

Alpha diversity can be used to evaluate the diversity and richness of soil microbial communities. The Good's coverage value (approximately 0.97) indicated that the sequencing depth well captured most microbes in the communities. A previous study showed that crop straw return could enrich microbial diversity [33]. In this study, the Chao1 and Shannon indexes of bacteria were significantly higher than those in CK at the $5^{\text {th }}$ post-returning stage (Table 3), indicating that residue return enriched the soil bacterial communities. Due to the cultivation of vegetable plants and the self-regulation of soil, the effect of residue return on the alpha diversity of soil bacteria was weakened at the $6^{\text {th }}$ pre-returning stage. However, the Shannon indexes of fungi communities was affected by residue return at the $6^{\text {th }}$ pre-returning stage.

Table 3. The alpha diversity of the microbial communities.

\begin{tabular}{|c|c|c|c|c|c|}
\hline \multirow{2}{*}{ Sampling Time } & \multirow{2}{*}{ Treatments } & \multicolumn{2}{|c|}{ Bacteria } & \multicolumn{2}{|c|}{ Fungi } \\
\hline & & Chao1 & Shannon & Chao1 & Shannon \\
\hline \multirow{2}{*}{$5^{\text {th }}$ post $(2020.09 .01)$} & CK & 3016.73 & 9.16 & 438.58 & 4.17 \\
\hline & $\mathrm{R}$ & $3320.29 *$ & $9.54 *$ & 497.31 & 4.71 \\
\hline \multirow{2}{*}{$6^{\text {th }}$ pre $(2020.12 .21)$} & CK & 3447.14 & 9.83 & 464.47 & 4.43 \\
\hline & $\mathrm{R}$ & 3574.52 & 9.79 & 532.10 & $5.07 *$ \\
\hline
\end{tabular}

$\mathrm{CK}$, the non-vegetable residue treatment; $\mathrm{R}$, the vegetable residue treatment; pre, the pre-returning stage; post, the post-returning stage; number 5 and 6 , the times of in situ vegetable residue return. Statistically significant differences were analysed between $C K$ and $R$ at each stage tested using $t$-test. ${ }^{*}, p<0.05$.

\subsubsection{Dominant Taxa at the Phylum Level Affected by Vegetable Residue Return}

The OTU representative sequences were analysed at a $97 \%$ similarity level. A total of 43 bacterial phyla and 16 fungal phyla were detected in each treatment. The predominant bacterial phyla of soil in the greenhouse were Proteobacteria (31.24-37.06\%), Actinobacteria (10.78-11.37\%), Acidobacteria (9.34-15.75\%), Chloroflexi (10.27-11.33\%), Gemmatimonadetes (7.72-10.74\%), Firmicutes (5.01-11.18\%), and Bacteroidetes (6.61-7.65\%) (Figure 1a). The total abundance of these phyla was more than $90 \%$. However, just limited bacterial phyla were significantly affected by the continuous residue return. At the $5^{\text {th }}$ post-returning stage, the relative abundance of Gemmatimonadetes increased by $39.12 \%$ (Figure 1a). Gemmatimonadetes was known to have a positive correlation with soil $\mathrm{N}$ content [34]. The increased relative abundance of Gemmatimonadetes echoes the increased soil TN and AN content (Table 2). Firmicutes can hydrolyse polysaccharides. Residue return significantly reduced the relative abundance of Firmicutes at the $5^{\text {th }}$ post-returning stage (CK: 11.18\%, R: 6.14\%; Figure 1a). The decomposed process of residue return was equal to the natural decomposition. As the decomposition proceeded, the relative abundance of Firmicutes could drastically decrease [35]. At the $6^{\text {th }}$ pre-returning stage, reduced relative abundance of Acidobacteria was observed in R (CK: 15.75\%, R: 9.34\%; Figure 1a). The relative abundance of Acidobacteria could reflect the nutrient level of soil [36]. This was most probably attributed to its weaker competitiveness under the higher nutrient level of soil in $\mathrm{R}$ (Table 2 ).

For fungi, Ascomycota was the predominant phylum of soil in the greenhouse, accounting for more than $60 \%$ of the fungal communities (Figure $1 \mathrm{~b}$ ); this result was consistent with the results found in field soil $[37,38]$. However, significant changes in the relative abundances of fungi phyla were only found at the $5^{\text {th }}$ post-returning stage. The relative abundance of Basidiomycota increased by $236.84 \%$ (CK: $0.38 \%$, R: $1.28 \%$; Figure 1b), while the relative abundance of Mortierellomycota decreased by $57.01 \%$ (CK: $5.49 \%$, R: 2.36\%; Figure 1b). Basidiomycota can decompose recalcitrant lignin [39], and Mortierellomycota can decompose sugars and simple polysaccharides [40]. These changes in the relative 
abundances of fungi phyla indicated that the decomposition process of vegetable residues might have switched from simple sugars to recalcitrant compounds.
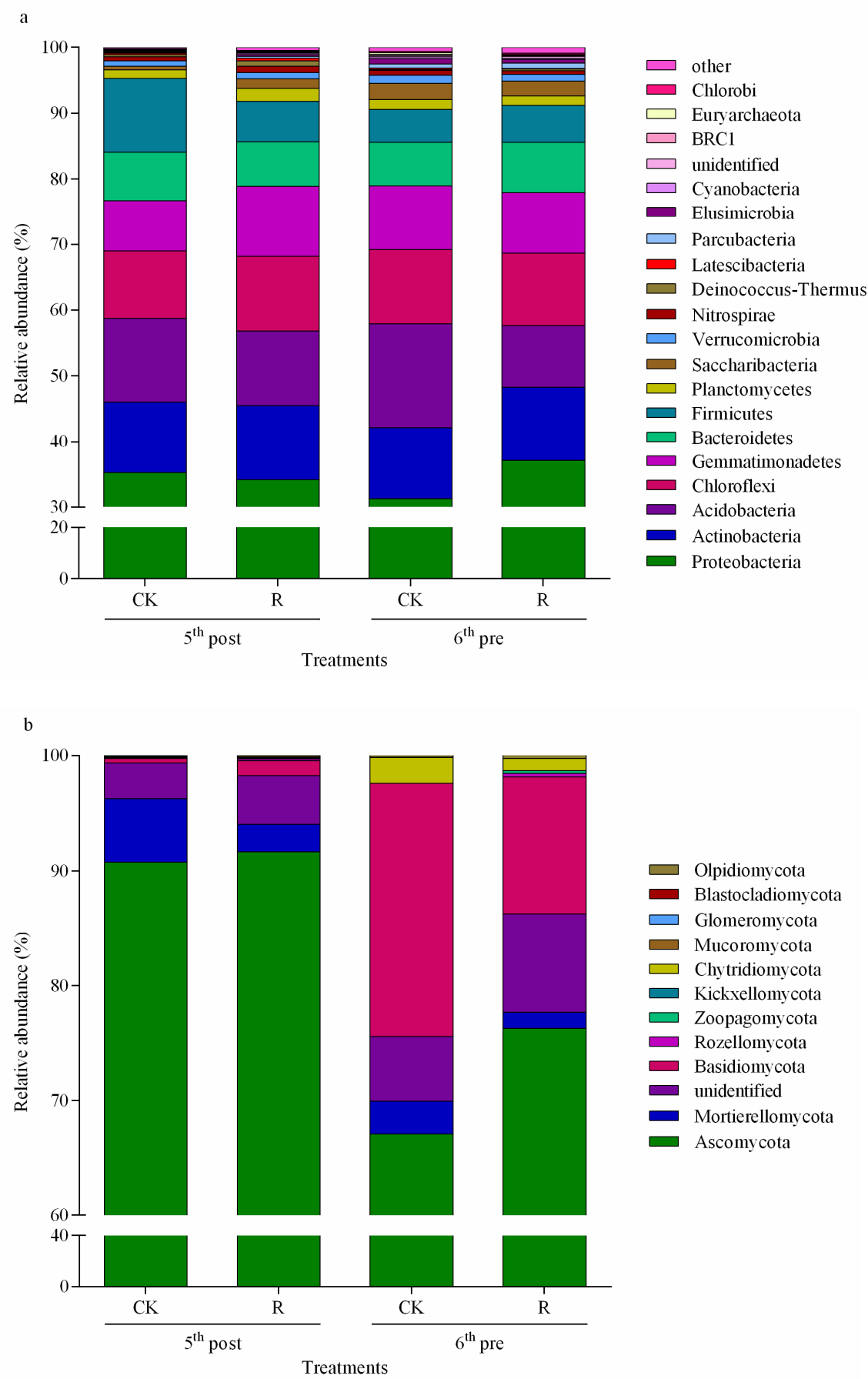

Figure 1. The microbial communities and the relative abundances of microbial phyla ((a) for bacteria, (b) for fungi). CK, the non-vegetable residue treatment; $\mathrm{R}$, the vegetable residue treatment; pre, the pre-returning stage; post, the post-returning stage; number 5 and 6 , the times of in situ vegetable residue return.

\subsubsection{Dominant Taxa at the Genus Level Affected by Vegetable Residue Return}

At the genus level, in addition to unidentified genera, 396 bacterial genera and 208 fungal genera were detected. Pseudomonas (1.90-7.52\%), Bacillus (2.34-6.08\%), Sphingomonas (1.79-3.44\%), Steroidobacter (1.75-2.73\%), RB41 (1.18-2.91\%), Nonomuraea (0.58-1.93\%), Microvirga (0.81-1.45\%), Gemmatimonas (0.69-1.34\%), Lysobacter (0.50-1.44\%), and Haliangium $(0.63-1.31 \%)$ were the most abundant bacterial genera (Figure 2a). Lophotrichus (7.47- 
13.50\%), Remersonia (0.66-26.57\%), Cephaliophora (3.15-11.19\%), Aspergillus (1.45-2.85\%), Chaetomium (1.39-2.81\%), and Mortierella (0.79-2.92\%) were the most abundant fungal genera (Figure $2 \mathrm{~b}$ ).

However, only some bacterial genera were significantly affected by continuous residue return. The relative abundance of Gemmatimonas, which belongs to Gemmatimonadetes, significantly increased at the $5^{\text {th }}$ post-returning stage (CK: $0.69 \%$, R: $1.14 \%$; Figure $2 a$ ) and the $6^{\text {th }}$ pre-returning stage (CK: $0.71 \%$, R: $1.34 \%$; Figure $2 \mathrm{a}$ ) with the increased soil TN and AN content (Table 2). The relative abundance of Haliangium (CK: 0.63\%, R: 0.98\%; Figure 2a) also increased after residue return at the $5^{\text {th }}$ post-returning stage, which was also known to have a positive correlation with the soil nutrient level [41]. The relative abundance of Bacillus (CK: 6.08\%, R: 3.19\%; Figure 2a), the main genus in Firmicutes, significantly decreased at the $5^{\text {th }}$ post-returning stage, although the difference with $\mathrm{CK}$ disappeared at the $6^{\text {th }}$ pre-returning stage.

Except the above taxa strongly linked with the soil nutrient level, the drop of soil $\mathrm{pH}$ by continuous residue return also resulted in a higher relative abundance of Cephaliophora at the $5^{\text {th }}$ post-returning stage (CK: $6.16 \%$, R5: $10.90 \%$; Figure $2 \mathrm{~b}$ ) and the $6^{\text {th }}$ pre-returning stage (CK: 3.15\%, R: 11.19\%; Figure 2b). Meanwhile, Cephaliophora can capture nematodes, but the species of nematodes are still unknown [42]. It could be speculated that residue return might increase the risk of infecting root-knot nematode disease, while it was not observed in our experiment. Therefore, the long-term effect of residue return on the root-knot nematode disease requires further research.

Common pathogenic microbes, such as Fusarium, Verticillium, and Cladosporium, were detected in the soil samples (Table S2). Fusarium is one of the most widespread and detrimental soilborne pathogens [43]. Verticillium infects most solanaceous crops and causes vascular wilt [44]. Cladosporium can cause tomato rot [45]. Excessive populations of pathogenic microbes could lead to quality deterioration and yield loss in vegetables. Surprisingly, the relative abundances of the above pathogenic microbes were not affected by residue return with good precaution of insect pests and diseases during the cultivation process. It can be speculated that short-term residue return would not increase the risk of detrimental pathogen occurrence in soil.

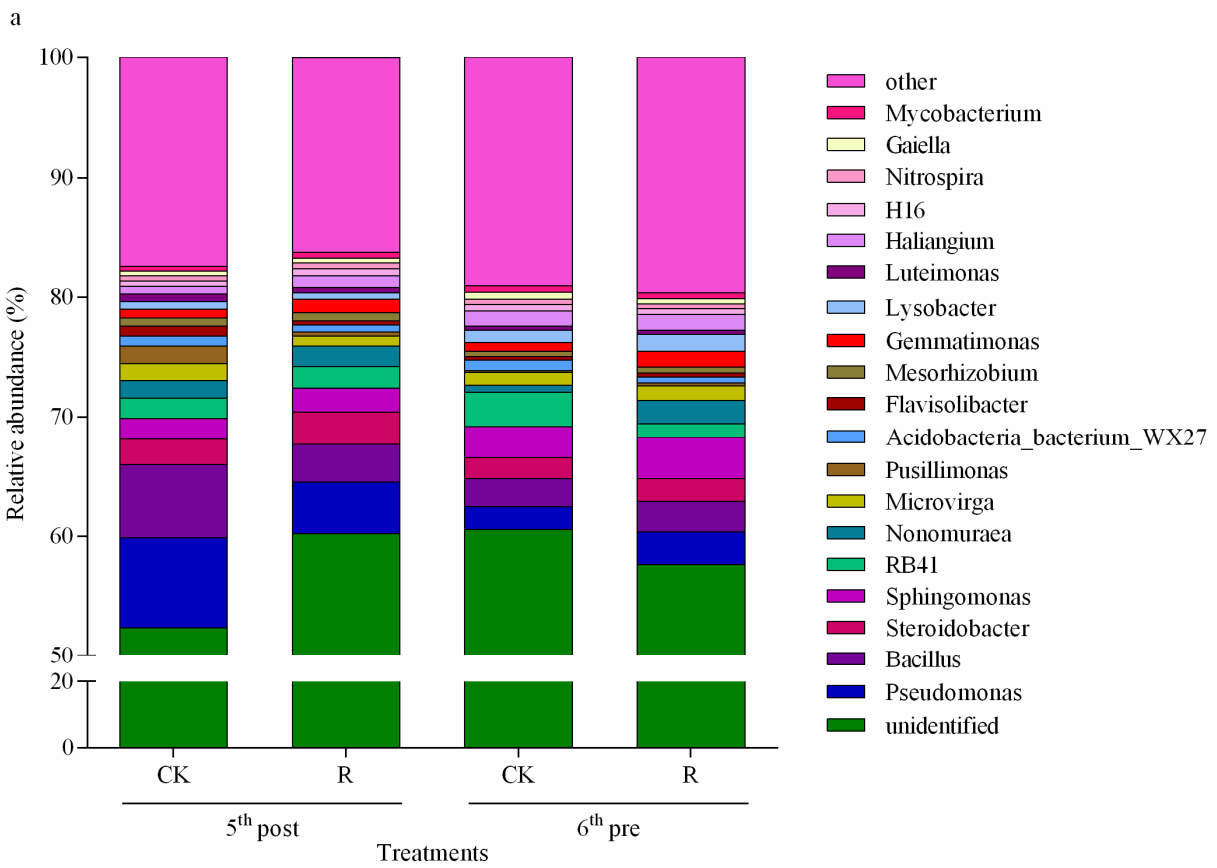

Figure 2. Cont. 


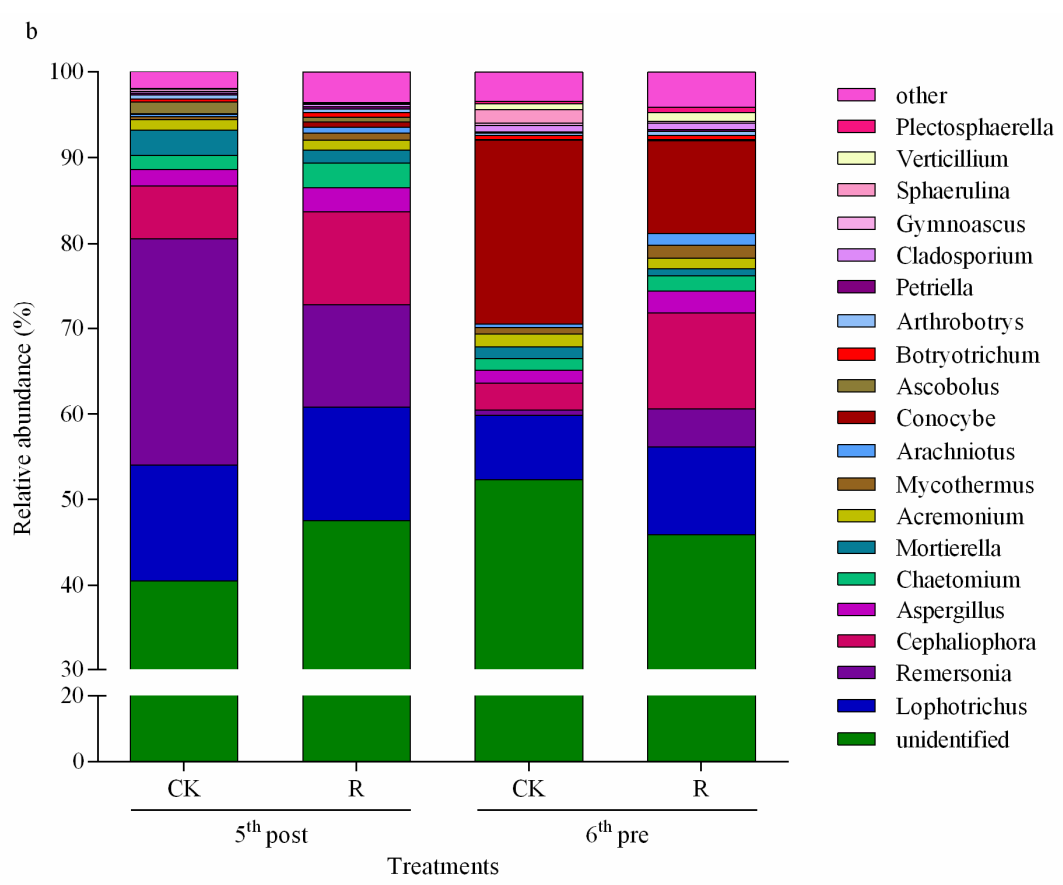

Figure 2. The microbial communities and the relative abundances of microbial genera ((a) for bacteria, (b) for fungi). CK, the non-vegetable residue treatment; $\mathrm{R}$, the vegetable residue treatment; pre, the pre-returning stage; post, the post-returning stage; number 5 and 6 , the times of in situ vegetable residue return.

\subsection{Correlations of Environmental Factors with the Abundances of the 10 Most Abundant Microbial Taxa}

Environmental factors are well known to have a significant influence on microbial communities [46]. Therefore, it was necessary to use RDA to reveal the correlations between the soil microbial communities and soil physicochemical characteristics. The length and direction of the arrows in the RDA plot reflect the importance of the variables and the type of correlation, respectively.

The RDA analysis at the $5^{\text {th }}$ post-returning stage and the $6^{\text {th }}$ pre-returning stage are shown in Figures 3 and 4, respectively. The first and second axes together explained 92.15\% and $97.19 \%$ of the dynamics of the bacterial and the fungal phylum data at the $5^{\text {th }}$ postreturning stage, respectively (Figure 3). In addition, the two axes together explained $96.29 \%$ and $93.81 \%$ of the dynamics of the bacterial and the fungal phylum data at the $6^{\text {th }}$ prereturning stage, respectively (Figure 4). The RDA analysis revealed an obvious community separation in the microbial phylum data at the $5^{\text {th }}$ post-returning stage, which indicated that residue return had a great effect on microbial communities at the post-returning stage. The soil nutrient level is the important component of microbial growth and can influence microbial communities [47]. Soil AN $(50.20 \%)$ was the prime factor driving the variation in bacterial communities at the $5^{\text {th }}$ post-returning stage (Figure $3 a$ ). AN, an important nutrient for microbes, was closely correlated with the abundances of the bacterial phyla Gemmatimonadetes and Saccharibacteria, reflecting the soil nutrient level [34], while Bacteroidetes, Acidobacteria, and Firmicute were negatively correlated with AN. The previous study also found this correlation [48]. In addition, soil bulk density $(58.80 \%)$ was the prime factor driving the variation in bacterial communities at the $6^{\text {th }}$ pre-returning stage, respectively (Figure 4a). Chloroflexi and Acidobacteria, as the facultative anaerobic or obligate anaerobic bacteria, were positively correlated with bulk density. For fungi, TK $(74.40 \%)$ and TP $(52.40 \%)$ were the controlling factors at the $5^{\text {th }}$ post-returning stage (Figure $3 \mathrm{~b}$ ) and the $6^{\text {th }}$ pre-returning stage (Figure $4 \mathrm{~b}$ ). The soil TK was positively correlated with Basidiomycota, which was negatively correlated with Mortierellomycota. In 
addition, the soil TP was positively correlated with Ascomycota and negatively correlated with Basidiomycota.

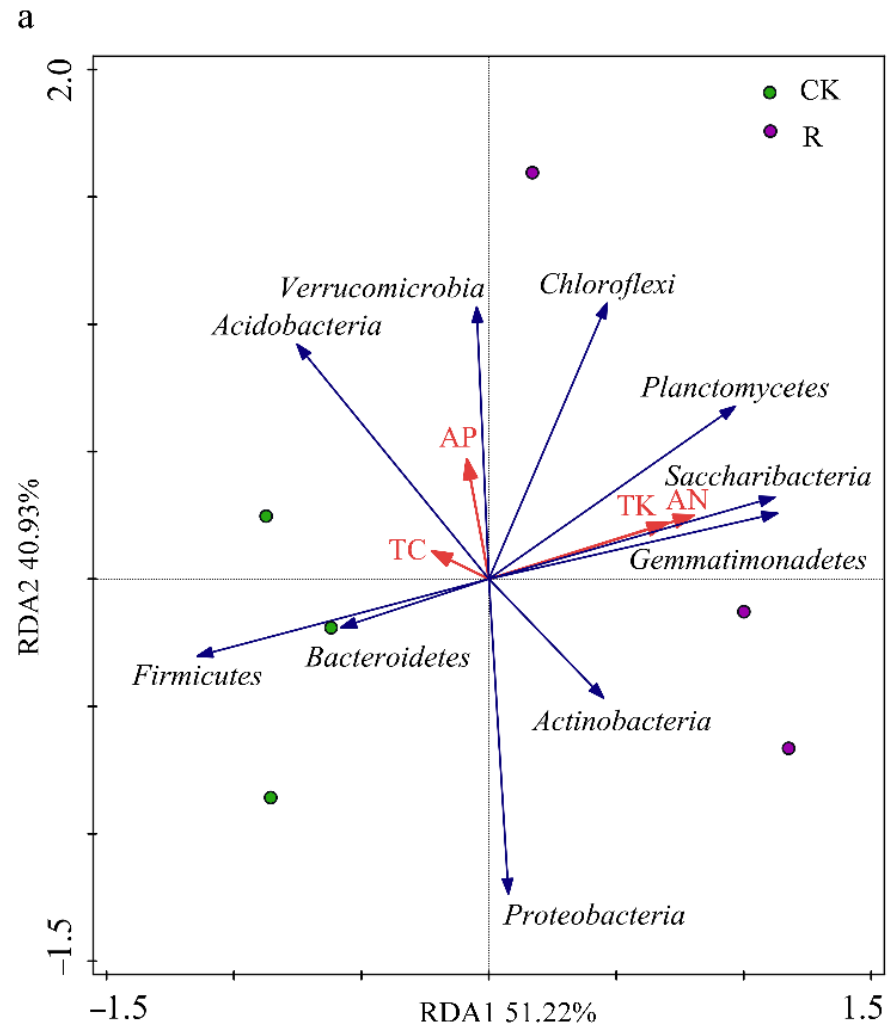

b

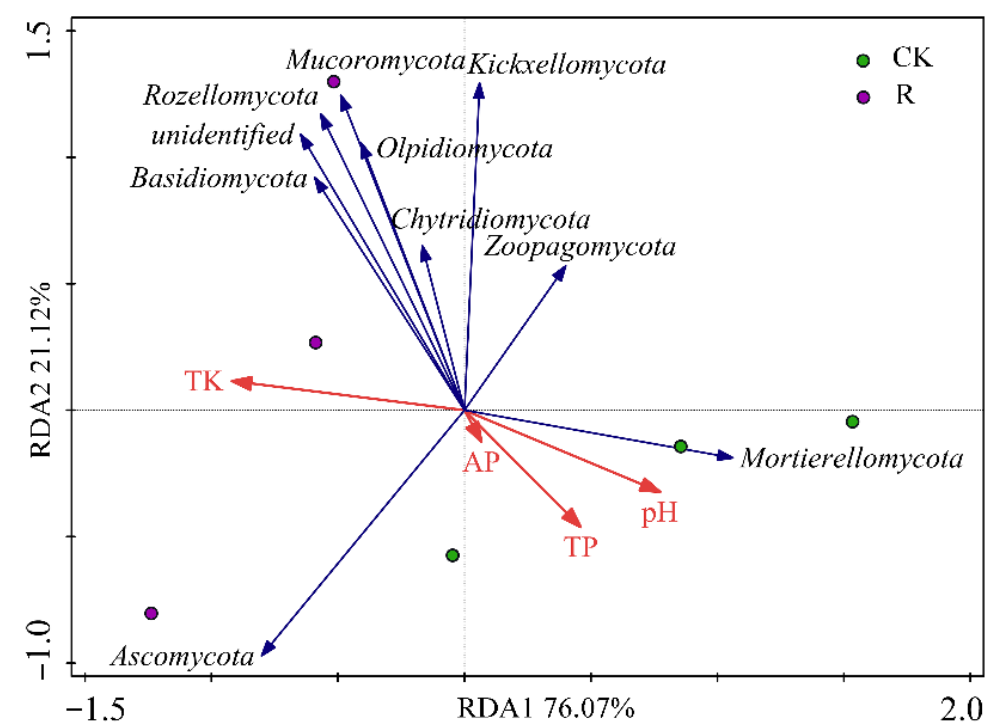

Figure 3. Redundancy analysis (RDA) between microbial communities and physicochemical characteristics at the $5^{\text {th }}$ post-returning stage ((a) for bacteria, (b) for fungi). CK, the non-vegetable residue treatment; $R$, the vegetable residue treatment. 
a

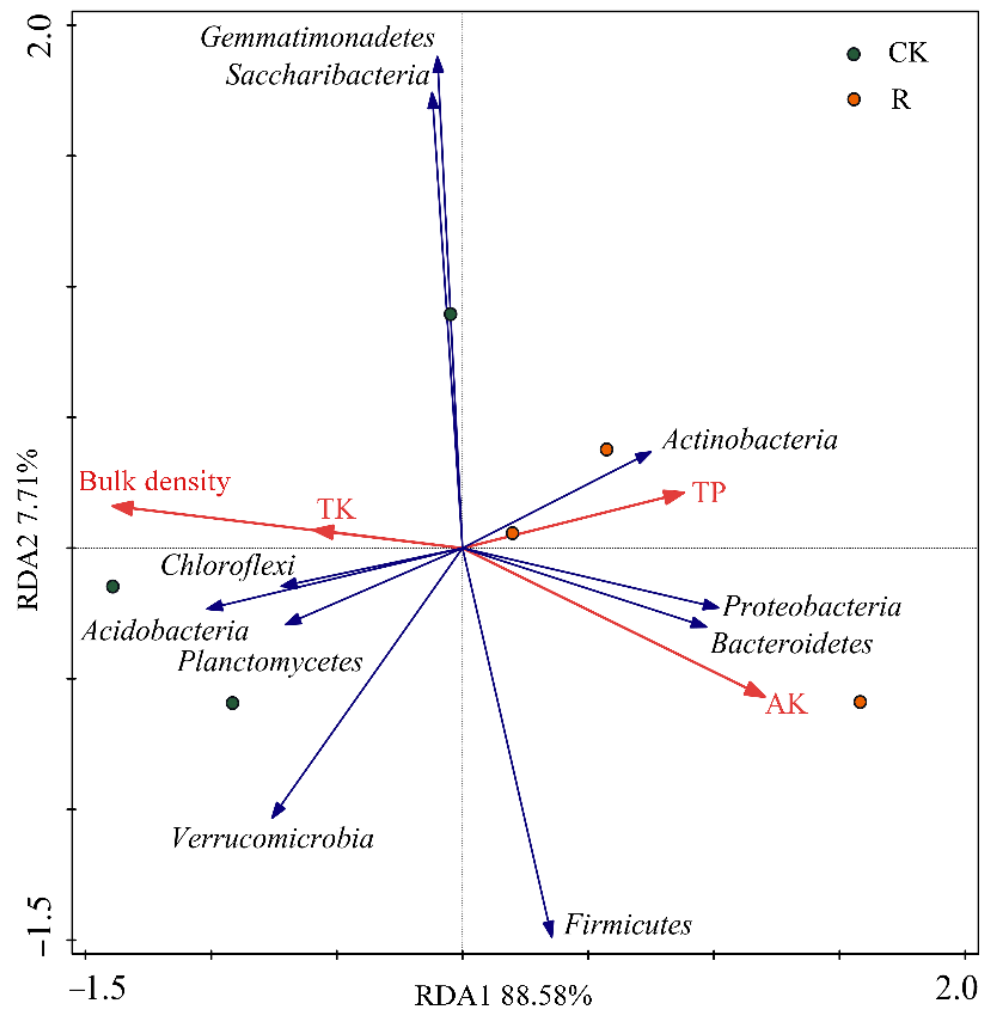

b

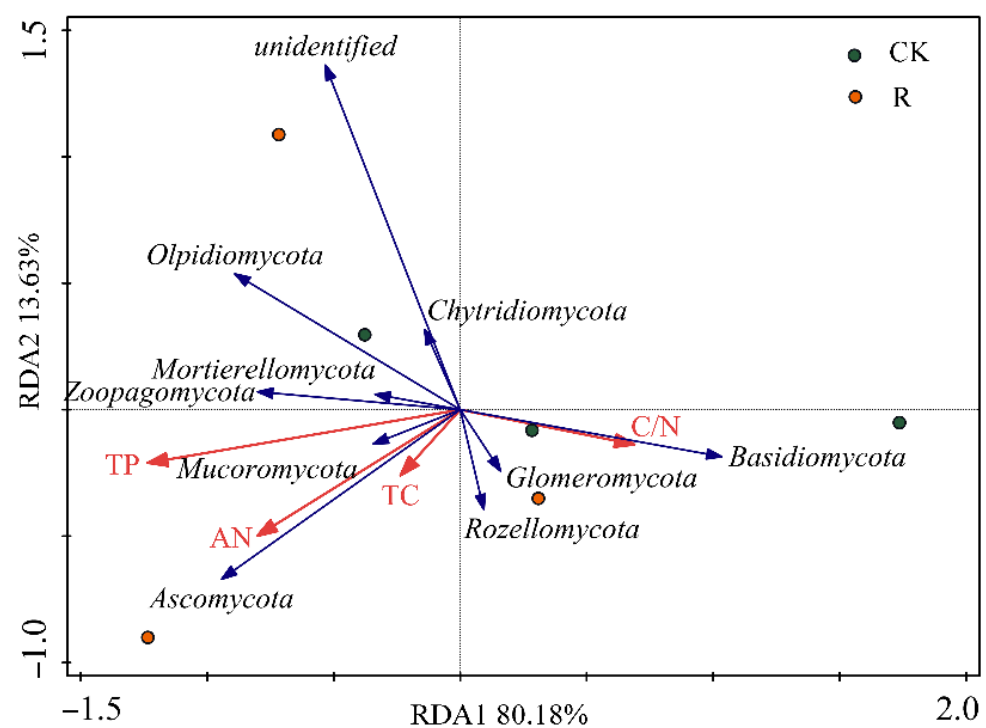

Figure 4. Redundancy analysis (RDA) between fungal communities and physicochemical characteristics at the $6^{\text {th }}$ pre-returning stage $((\mathbf{a})$ for bacteria, (b) for fungi). CK, the non-vegetable residue treatment; $R$, the vegetable residue treatment.

\subsection{Physicochemical Characteristics of Vegetable Residue and Vegetable Growth}

Physicochemical characteristics of vegetable residues in $\mathrm{R}$ and CK did not show an obvious difference or consistency. It was found that the TC content of vegetable residues in $R$ increased by $2.12-5.02 \%$ compared with those in CK at the $2^{\text {nd }}$ and the $4^{\text {th }}$ pre-returning stages (Table 4 ). The TN content of vegetable residues increased by $12.24 \%$, and the C/N ratio of vegetable residues decreased by $9.14 \%$ at the $3^{\text {rd }}$ pre-returning stage (Table 4 ). 
Meanwhile, the TK content of vegetable residues increased by $22.67 \%$ and $24.51 \%$ at the $3^{\text {rd }}$ and $4^{\text {th }}$ pre-returning stages, respectively, compared with those in CK (Table 4). In addition, residue return increased the TP content of vegetable residues for $43.96 \%$ and $22.18 \%$ at the $3^{\text {rd }}$ and $6^{\text {th }}$ pre-returning stages, respectively.

Table 4. The dry weight and physicochemical characteristics of vegetable residues.

\begin{tabular}{|c|c|c|c|c|c|c|c|c|}
\hline $\begin{array}{l}\text { Sampling } \\
\text { Times }\end{array}$ & $\begin{array}{l}\text { Residues } \\
\text { Species }\end{array}$ & Treatments & $\begin{array}{c}\text { Dry Weight } \\
\left(\mathrm{kg} \cdot \mathrm{ha}^{-1}\right)\end{array}$ & $\begin{array}{c}\text { TC } \\
\left(\mathrm{g} \cdot \mathrm{kg}^{-1}\right)\end{array}$ & $\begin{array}{c}\mathrm{TN} \\
\left(\mathrm{g} \cdot \mathrm{kg}^{-1}\right)\end{array}$ & $\mathbf{C} / \mathbf{N}$ & $\begin{array}{c}\text { TP } \\
\left(\mathrm{g} \cdot \mathrm{kg}^{-1}\right)\end{array}$ & $\begin{array}{c}\text { TK } \\
\left(\mathrm{g} \cdot \mathrm{kg}^{-1}\right)\end{array}$ \\
\hline \multirow{2}{*}{$\begin{array}{c}2^{\text {nd }} \text { pre } \\
(2017.12 .21)\end{array}$} & \multirow{2}{*}{ Cucumber } & CK & 2014.43 & 376.35 & 31.11 & 12.16 & 3.65 & 25.34 \\
\hline & & $\mathrm{R}$ & 1640.51 & $384.31 *$ & 31.61 & 12.18 & 3.48 & 25.73 \\
\hline \multirow{2}{*}{$\begin{array}{c}3^{\text {rd }} \text { pre } \\
(2018.07 .26)\end{array}$} & \multirow{2}{*}{ Tomato } & CK & 2355.90 & 319.72 & 31.86 & 9.96 & 3.64 & 41.90 \\
\hline & & $\mathrm{R}$ & 2380.74 & 325.74 & $35.76^{*}$ & $9.05 *$ & $5.24 *$ & $51.40 *$ \\
\hline \multirow{2}{*}{$\begin{array}{c}4^{\text {th }} \text { pre } \\
(2019.07 .15)\end{array}$} & \multirow{2}{*}{ Cucumber } & CK & 2173.99 & 310.05 & 21.55 & 14.41 & 3.24 & 24.44 \\
\hline & & $\mathrm{R}$ & 2594.54 * & $325.63 *$ & 22.09 & 14.81 & 3.39 & 30.43 * \\
\hline \multirow{2}{*}{$\begin{array}{c}5^{\text {th }} \text { pre } \\
(2020.07 .15)\end{array}$} & \multirow{2}{*}{ Tomato } & CK & 2129.83 & 313.58 & 28.49 & 10.93 & 3.26 & 50.02 \\
\hline & & $\mathrm{R}$ & 2643.95 * & 313.22 & 30.44 & 10.34 & 3.57 & 51.32 \\
\hline \multirow{2}{*}{$\begin{array}{c}6^{\text {th }} \text { pre } \\
(2020.12 .21)\end{array}$} & \multirow{2}{*}{ Cucumber } & CK & 1432.81 & 352.55 & 39.61 & 8.94 & 5.77 & 37.06 \\
\hline & & $\mathrm{R}$ & $1567.76^{*}$ & 362.26 & 39.71 & 9.16 & $7.05^{*}$ & 41.29 \\
\hline
\end{tabular}

$\mathrm{CK}$, the non-vegetable residue treatment; $\mathrm{R}$, the vegetable residue treatment; pre, the pre-returning stage; number from 2 to 6 , the times of in situ vegetable residue return. TC, total carbon; TN, total nitrogen; $\mathrm{C} / \mathrm{N}$, the ratio of TC to TN; TP, total phosphorus; TK, total potassium. Statistically significant differences were analysed between CK and $\mathrm{R}$ at each stage using $t$-test. * $p<0.05$.

In situ vegetable residue return increased the dry weight of vegetable residues by $9.43-$ $24.14 \%$ at the $4^{\text {th }}$ to $6^{\text {th }}$ pre-returning stages (Table 4 ). When residue return was conducted 3,4 , and 5 times, fruit yield remarkably increased by $8.24 \%, 7.53 \%$ and $8.23 \%$ at the $4^{\text {th }}, 5^{\text {th }}$, and $6^{\text {th }}$ pre-returning stages, respectively (Figure 5a). Similar promotion was also found in crop straw return $[49,50]$ and compost addition [23,51]. This result might be attributed to the high dry weight of vegetable residue returned to the soil at the $4^{\text {th }}$ pre-returning stage and the continuous improvement of soil physicochemical characteristics.

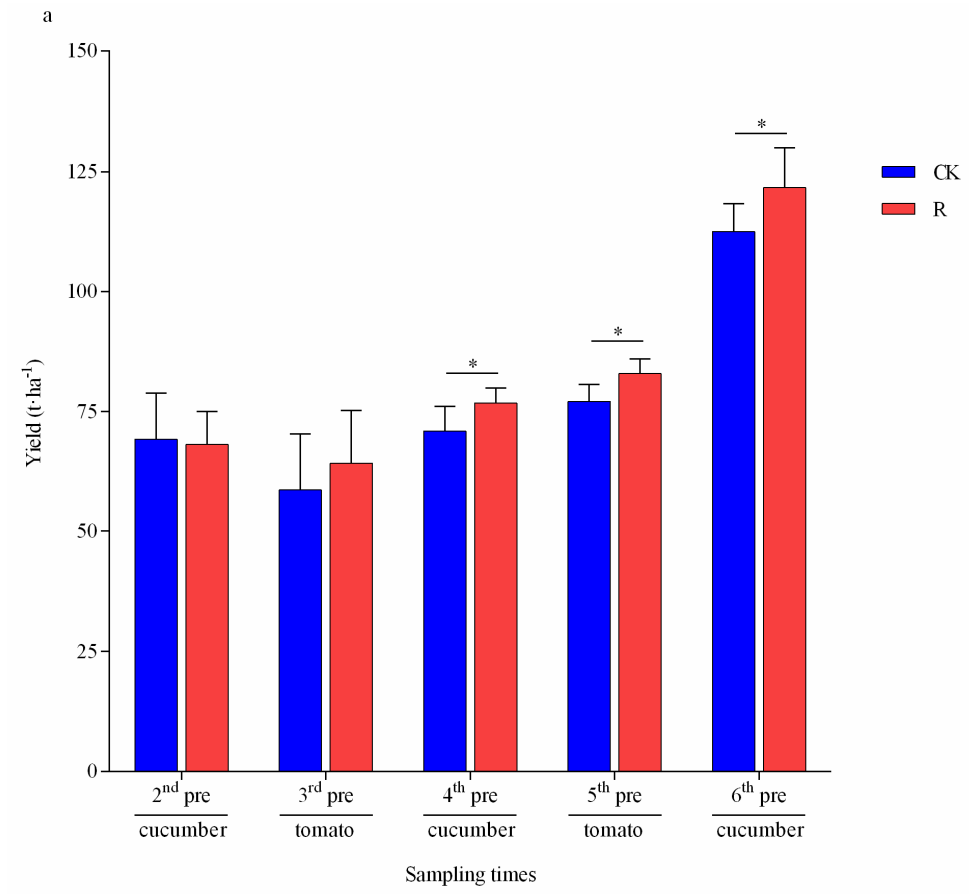

Figure 5. Cont. 


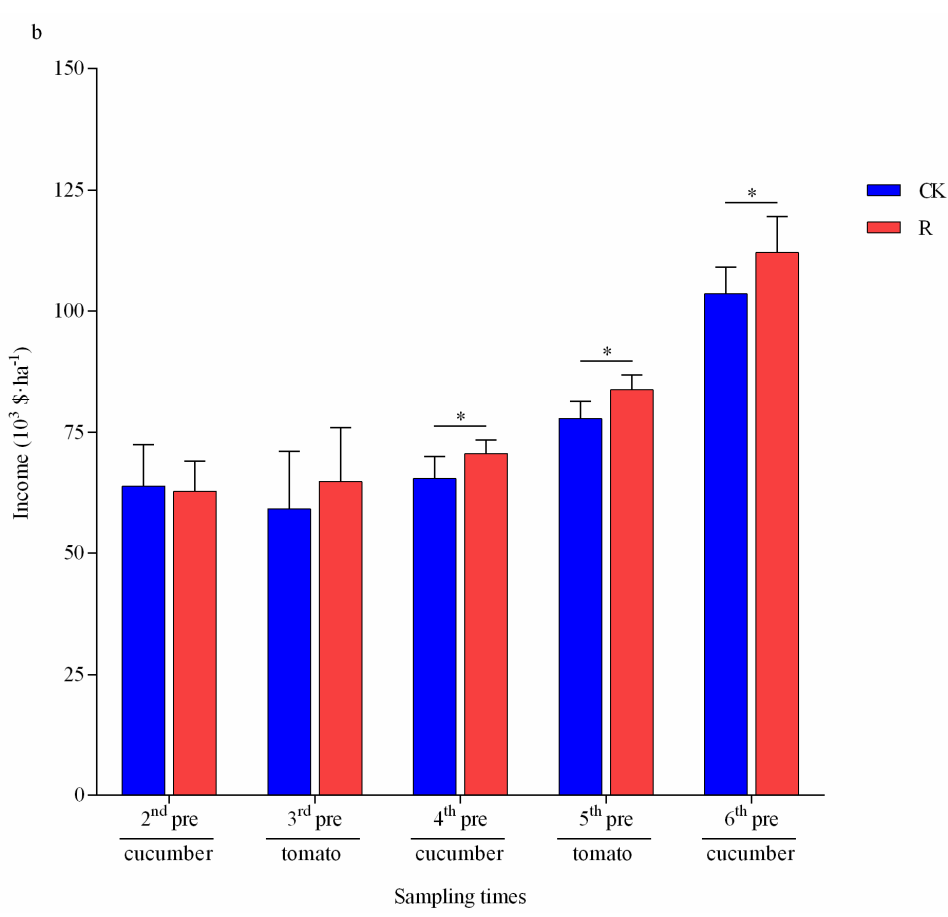

Figure 5. The fruit yield (a) and the income of fruit yield (b) after in situ vegetable residue return. $\mathrm{CK}$, the non-vegetable residue treatment; $\mathrm{R}$, the vegetable residue treatment; pre, the pre-returning stage; number from 2 to 6 , the times of in situ vegetable residue return. Statistically significant differences were analysed between $\mathrm{CK}$ and $\mathrm{R}$ at each stage using t-test. ${ }^{*}, p<0.05$. Vegetable from Shouguang holds a big market share in Beijing. The average sale prices of cucumber and tomato at the largest vegetable market in Beijing from 2017 to 2020 were approximately $0.92 \mathrm{USD} \cdot \mathrm{kg}^{-1}$ and 1.01 USD $\mathrm{kg}^{-1}$, respectively.

The increased soil AK content caused by residue return could contribute to the higher yield accumulation [52,53]. It has been reported that the accumulation of $\mathrm{K}$ in fruit accounts for the highest proportion of the total $\mathrm{K}$ absorption amount of vegetable plants [15]. The increased fruit yield in $\mathrm{R}$ indicated that residue return possibly contributed to much more $\mathrm{K}$ absorption amount of vegetable plants compared to CK. In addition, the TK contents of vegetable residue in $\mathrm{R}$ after the $2^{\text {nd }}$ and the $3^{\text {rd }}$ residue return were higher than those in CK (Table 4), while the soil AK contents in R were higher than those in CK at each stage (Table 2). It indicated that in situ vegetable residue return could not only supply $\mathrm{K}$ to soil, but also likely accelerate the transformation of mineral $\mathrm{K}$ to exchangeable $\mathrm{K}$ in soil, resulting in decreased soil TK content.

In situ vegetable residue return did not aggravate the occurrence of common vegetable diseases and insect pests when the appropriate precautionary measures were taken. However, it is worth noting that residue return in winter also did not aggravate the occurrence of disease. Hence, the high soil temperature might not be necessary to prevent pathogen infestation by residue return under the adequately preventive measures. The carried diseases and insect pests of vegetable residues, as the biggest challenge of residue return, has been well controlled with the development of cultivation techniques and degradable biological agents.

Based on our measured results and the existing cultivated areas of tomato and cucumber, it has been estimated that approximately 3.09 million tons of dry vegetable residues of tomato and cucumber are produced in protected cultivation each year in China. Nutrients in vegetable residues exist in organic and inorganic forms. After residue return, inorganic nutrients can be directly recycled, while organic nutrients can also be used after decomposition. $\mathrm{N}$ and $\mathrm{P}$ in vegetable residues are found in organic and inorganic forms, some of which needs to be converted to inorganic forms and then be used; $\mathrm{K}$ can be directly reused in its ionic state. According to the average result of the physicochemical characteristics of 
cucumber and tomato residues in this study, it is estimated that the application of in situ vegetable residue return in China could provide about 96.29 kilotons of $\mathrm{N}, 132.14$ kilotons of $\mathrm{K}$, and 13.25 kilotons of $\mathrm{P}$, greatly contributing to reducing chemical fertilizer inputs in protected cultivation. In particular, cucumber and tomato are K-favouring vegetables, which resulted in a conspicuous enhancement in soil AK content via residue return (Table 2). Therefore, the application of in situ vegetable residue return could achieve a win-win situation by supplying nutrients for vegetables while reducing resource waste and environmental pollution.

\subsection{Feasibility Assessment}

The above results have demonstrated that in situ vegetable residue return could improve soil physicochemical characteristics. Meanwhile, residue return did not aggravate the occurrence of common vegetable diseases and insect pests when the appropriate precautionary measures were taken. Hence, in situ vegetable residue return could be a feasible technique applied in the use of vegetable residue.

In addition, in situ vegetable residue return reduced the disposal expense of vegetable residues and brought an additional income by increasing fruit yield. According to the survey of the labour market in Shouguang, which has the biggest scale in protected cultivation in China, removing vegetable residues requires one labourer for $180 \mathrm{~h} \cdot \mathrm{ha}^{-1}$, and the average salary of one labourer is around $4.58 \mathrm{USD} \cdot \mathrm{h}^{-1}(1 \mathrm{USD}=6.55 \mathrm{RMB})$. The traditional method of disposing of vegetable residues cost approximately $824.40 \mathrm{USD} \cdot \mathrm{ha}^{-1}$, while in situ vegetable residue return performed by straw-returning machine costs only 343.51 USD $\cdot \mathrm{ha}^{-1}$, contributing to a cost saving of $480.89 \mathrm{USD} \cdot \mathrm{ha}^{-1}$.

After continuous residue return for 3 times, fruit yield gained a remarkable increase. Compared to $\mathrm{CK}$, residue return conducted 3, 4, and 5 times correspondingly increased fruit yield by $5.85 \mathrm{t} \cdot \mathrm{ha}^{-1}, 5.81 \mathrm{t} \cdot \mathrm{ha}^{-1}$, and $9.26 \mathrm{t} \cdot \mathrm{ha}^{-1}$ (Figure $5 \mathrm{a}$ ), which brought the additional income for 5382.0 USD ha $^{-1}, 5868.1 \mathrm{USD} \cdot \mathrm{ha}^{-1}$, and 8519.2 USD.ha ${ }^{-1}$ (Figure 5b), respectively. In situ vegetable residue return brought about additional profits of $5382.0 \mathrm{USD} \cdot \mathrm{ha}^{-1}$, 5868.1 USD.ha ${ }^{-1}$, and 8519.2 USD $\cdot \mathrm{ha}^{-1}$, respectively. Considering the enormous area of protected vegetable cultivation in China, in situ vegetable residue return has great potential to bring about substantial economic benefits.

\section{Conclusions}

In situ vegetable residue return greatly increased soil AN and AK contents, along with slightly reduced soil $\mathrm{pH}$ and bulk density. Residue return affected the microbial communities with noticeable changes of Gemmatimonadetes, Firmicutes, Acidobacteria, Basidiomycota, and Mortierellomycota. Under the condition of sufficient precautions fighting against diseases and insect pests, in situ vegetable residue return contributed to great increase of fruit yield and additional profits. Based on the techno-economic analysis, in situ vegetable residue return could be applied as a feasible technique in the Chinese solar greenhouse. Considering the tremendous production scale of protected vegetable cultivation in China, in situ vegetable residue return would have a wide application prospect.

Supplementary Materials: The following are available online at https:/ / www.mdpi.com/article/10 .3390/agronomy11091828/s1, Table S1: The pesticides used for common insect pests and diseases, Table S2: The relative abundances of main harmful microbial genera.

Author Contributions: X.W.: Conceptualization, Methodology, Investigation, Data curation, Formal analysis, writing —original draft, writing_review and editing. Y.L.: Conceptualization, Methodology, Project administration, writing-review and editing, Supervision. X.F.: Methodology. C.H.: Conceptualization, Methodology. Y.Y.: Conceptualization, Methodology. M.S.: Conceptualization, Methodology. C.D.: Methodology. J.W.: Conceptualization, Methodology, Project administration, Supervision, writing-review and editing. X.Y.: Resources, Conceptualization, Methodology, Project administration, Supervision, writing - review and editing, Funding acquisition. All authors have read and agreed to the published version of the manuscript. 
Funding: This work was funded by the Earmarked Fund for Modern Agro-industry Technology Research System (CARS-25-C-01), the National Key Research and Development Program of China (2019YFD1001903), the Science and Technology Innovation Program of the Chinese Academy of Agricultural Sciences (CAAS-ASTIP-IVFCAAS), and the Key Laboratory of Horticultural Crop Biology and Germplasm Innovation, Ministry of Agriculture, China.

Institutional Review Board Statement: Not applicable.

Informed Consent Statement: Not applicable.

Data Availability Statement: Data is contained within the article or supplementary material.

Conflicts of Interest: The authors declare no conflict of interest.

\section{References}

1. Du, P.X.; Han, X.; Gao, J.Y.; Chen, Q.; Li, Y.M. Potential analysis on high efficient utilization of waste vegetable resources in China. China Veg. 2015, 1, 15-20. [CrossRef]

2. Zhang, Z.H.; Ma, Z.H. Overview of Chinese protected vegetable industry and key points of development during the 13th five-year plan: Interview with Zhang Zhenhe, vice president of China vegetable association. China Veg. 2017, 5, 1-5. [CrossRef]

3. Ros, M.; de Souza Oliveira Filho, J.; Murcia, M.D.P.; Bustamante, M.A.; Moral, R.; Coll, M.D.; Santisima-Trinidad, A.B.L.; Pascual, J.A. Mesophilic anaerobic digestion of pig slurry and fruit and vegetable waste: Dissection of the microbial community structure. J. Clean. Prod. 2017, 156, 757-765. [CrossRef]

4. Cui, H.-Y.; Zhang, S.-B.; Zhao, M.-Y.; Zhao, Y.; Wei, Z.-M. Parallel faction analysis combined with two-dimensional correlation spectroscopy reveal the characteristics of mercury-composting-derived dissolved organic matter interactions. J. Hazard. Mater. 2020, 384, 121395. [CrossRef]

5. Mahmoodi, P.; Karimi, K.; Taherzadeh, M.J. Hydrothermal processing as pretreatment for efficient production of ethanol and biogas from municipal solid waste. Bioresour. Technol. 2018, 261, 166-175. [CrossRef] [PubMed]

6. Bouallagui, H.; Lahdheb, H.; Ben Romdan, E.; Rachdi, B.; Hamdi, M. Improvement of fruit and vegetable waste anaerobic digestion performance and stability with co-substrates addition. J. Environ. Manag. 2009, 90, 1844-1849. [CrossRef] [PubMed]

7. Awasthi, M.K.; Sarsaiya, S.; Wainaina, S.; Rajendran, K.; Kumar, S.; Quan, W.; Duan, Y.; Awasthi, S.K.; Chen, H.; Pandey, A.; et al. A critical review of organic manure biorefinery models toward sustainable circular bioeconomy: Technological challenges, advancements, innovations, and future perspectives. Renew. Sustain. Energy Rev. 2019, 111, 115-131. [CrossRef]

8. Sánchez, J.Ó.; Ospina, D.A.; Montoya, S. Compost supplementation with nutrients and microorganisms in composting process. Waste Manag. 2017, 69, 136-153. [CrossRef]

9. Zhang, Y.; Zhao, Y.; Chen, Y.; Lu, Q.; Li, M.; Wang, X.; Wei, Y.; Xie, X.; Wei, Z. A regulating method for reducing nitrogen loss based on enriched ammonia-oxidizing bacteria during composting. Bioresour. Technol. 2016, 221, 276-283. [CrossRef]

10. Meena, M.D.; Yadav, R.K.; Narjary, B.; Yadav, G.; Jat, H.S.; Sheoran, P.; Meena, M.K.; Antil, R.S.; Meena, B.L.; Singh, H.V.; et al. Municipal solid waste (MSW): Strategies to improve salt affected soil sustainability: A review. Waste Manag. 2019, 84, 38-53. [CrossRef]

11. Wang, R.; Zhao, Y.; Xie, X.; Mohamed, T.A.; Zhu, L.; Tang, Y.; Chen, Y.; Wei, Z. Role of NH3 recycling on nitrogen fractions during sludge composting. Bioresour. Technol. 2020, 295, 122175. [CrossRef]

12. Wang, X.-D.; He, C.; Cheng, H.-Y.; Liu, B.-Y.; Li, S.-S.; Wang, Q.; Liu, Y.; Zhao, X.; Zhang, H.-L. Responses of greenhouse gas emissions to residue returning in China's croplands and influential factors: A meta-analysis. J. Environ. Manag. 2021, $289,112486$. [CrossRef] [PubMed]

13. Jiang, W.; Yan, T.; Chen, B. Impact of media channels and social interactions on the adoption of straw return by Chinese farmers. Sci. Total. Environ. 2021, 756, 144078. [CrossRef]

14. Fernández-Gómez, M.J.; Romero, E.; Nogales, R. Feasibility of vermicomposting for vegetable greenhouse waste recycling. Bioresour. Technol. 2010, 101, 9654-9660. [CrossRef] [PubMed]

15. He, S.; Liang, B.; Wu, D.; Wang, Y.; Li, J. Nutrient demand of tomato in the facility vegetable field. Acta Agric. Boreali-Sin. 2020, 35, 61-67. [CrossRef]

16. Rayment, G.E.; Lyons, D.J. Soil Chemical Methods-Australasia; CSIRO Publishing: Collingwood, Australia, 2011.

17. Qi, Y.; Chen, T.; Pu, J.; Yang, F.; Shukla, M.K.; Chang, Q. Response of soil physical, chemical and microbial biomass properties to land use changes in fixed desertified land. Catena 2018, 160, 339-344. [CrossRef]

18. Tian, X. Study on ICP-AES Analysis Method of Simultaneously High-Speed Determination for Quick-Acting P and K in the Soil. Chin. J. Spectrosc. Lab. 1997, 14, 40-43. Available online: https://en.cnki.com.cn/Article_en/CJFDTotal-GPSS199704010.htm (accessed on 7 July 2021).

19. Hao, H.-P.; Li, H.; Jiang, C.-D.; Tang, Y.-D.; Shi, L. Ion micro-distribution in varying aged leaves in salt-treated cucumber seedlings. Plant Physiol. Biochem. 2018, 129, 71-76. [CrossRef]

20. Zhang, X.; Tian, X.; Ma, L.; Feng, B.; Liu, Q.; Yuan, L.; Fan, C.; Huang, H.; Yang, Q. Biodiversity of the Symbiotic Bacteria Associated with Toxic Marine Dinoflagellate Alexandrium tamarense. J. Biosci. Med. 2015, 03, 23-28. [CrossRef] 
21. Bengtsson-Palme, J.; Ryberg, M.; Hartmann, M.; Branco, S.M.; Wang, Z.; Godhe, A.; De Wit, P.; Sánchez-García, M.; Ebersberger, I.; Sousa, F.; et al. Improved software detection and extraction of ITS1 and ITS2 from ribosomal ITS sequences of fungi and other eukaryotes for analysis of environmental sequencing data. Methods Ecol. Evol. 2013, 4, 914-919. [CrossRef]

22. Edgar, R.C. UPARSE: Highly accurate OTU sequences from microbial amplicon reads. Nat. Methods 2013, 10, 996-998. [CrossRef]

23. Gao, Y.; Yu, H.; Liu, P.; Ma, C.; Li, Q.; Jiang, W. Ending composting during the thermophilic phase improves cultivation substrate properties and increasing winter cucumber yield. Waste Manag. 2018, 79, 260-272. [CrossRef] [PubMed]

24. Tong, C.; Xiao, H.; Tang, G.; Wang, H.; Huang, T.; Xia, H.; Keith, S.J.; Li, Y.; Liu, S.; Wu, J. Long-term fertilizer effects on organic carbon and total nitrogen and coupling relationships of $C$ and $N$ in paddy soils in subtropical China. Soil Till. Res. 2009, 106, 8-14. [CrossRef]

25. Yanni, S.F.; Whalen, J.K.; Simpson, M.J.; Janzen, H.H. Plant lignin and nitrogen contents control carbon dioxide production and nitrogen mineralization in soils incubated with Bt and non-Bt corn residues. Soil Biol. Biochem. 2011, 43, 63-69. [CrossRef]

26. Saha, P.; Miah, M.; Hossain, A.; Rahman, F.; Saleque, M. Contribution of rice straw to potassium supply in rice-fallow-rice cropping pattern. Bangladesh J. Agric. Res. 2010, 34, 633-643. [CrossRef]

27. Sheng, X.F.; He, L.Y. Solubilization of potassium-bearing minerals by a wild-type strain of Bacillus edaphicus and its mutants and increased potassium uptake by wheat. Can. J. Microbiol. 2006, 52, 66-72. [CrossRef]

28. Gao, M.; Liang, F.; Yu, A.; Li, B.; Yang, L. Evaluation of stability and maturity during forced-aeration composting of chicken manure and sawdust at different $\mathrm{C} / \mathrm{N}$ ratios. Chemosphere 2010, 78, 614-619. [CrossRef] [PubMed]

29. Wong, J.; Mak, K.; Chan, N.; Lam, A.; Fang, M.; Zhou, L.; Wu, Q.; Liao, X. Co-composting of soybean residues and leaves in Hong Kong. Bioresour. Technol. 2001, 76, 99-106. [CrossRef]

30. Chen, D.; Xing, W.; Lan, Z.; Saleem, M.; Wu, Y.; Hu, S.; Bai, Y. Direct and indirect effects of nitrogen enrichment on soil organisms and carbon and nitrogen mineralization in a semi-arid grassland. Funct. Ecol. 2019, 33, 175-187. [CrossRef]

31. Chen, S.H.; Zhu, Z.L.; Wu, J.; Liu, D.H.; Wang, C.Q. Decomposition characteristics of straw return to soil and its effect on soil fertility in Purple Hilly Region. J. Soil Water Conserv. 2006, 20, 141-144. [CrossRef]

32. Hou, L.; Chen, X.; Kuhn, L.; Huang, J. The effectiveness of regulations and technologies on sustainable use of crop residue in Northeast China. Energy Econ. 2019, 81, 519-527. [CrossRef]

33. Li, H.; Dai, M.; Dai, S.; Dong, X. Current status and environment impact of direct straw return in China's cropland-A review. Ecotoxicol. Environ. Saf. 2018, 159, 293-300. [CrossRef] [PubMed]

34. DeBruyn, J.M.; Nixon, L.T.; Fawaz, M.N.; Johnson, A.M.; Radosevich, M. Global Biogeography and Quantitative Seasonal Dynamics of Gemmatimonadetes in Soil. Appl. Environ. Microbiol. 2011, 77, 6295-6300. [CrossRef]

35. Liu, L.; Wang, S.; Guo, X.; Zhao, T.; Zhang, B. Succession and diversity of microorganisms and their association with physicochemical properties during green waste thermophilic composting. Waste Manag. 2018, 73, 101-112. [CrossRef]

36. Fierer, N.; Bradford, M.A.; Jackson, R.B. Toward an ecological classification of soil bacteria. Ecology 2007, 88, 1354-1364. [CrossRef]

37. Chen, S.; Waghmode, T.R.; Sun, R.; Kuramae, E.; Hu, C.; Liu, B. Root-associated microbiomes of wheat under the combined effect of plant development and nitrogen fertilization. Microbiome 2019, 7, 1-13. [CrossRef] [PubMed]

38. He, X.; Han, L.; Fu, B.; Du, S.; Liu, Y.; Huang, G. Effect and microbial reaction mechanism of rice straw biochar on pore methane production during mainstream large-scale aerobic composting in China. J. Clean. Prod. 2019, 215, 1223-1232. [CrossRef]

39. Schmidt-Dannert, C. Biocatalytic portfolio of Basidiomycota. Curr. Opin. Chem. Biol. 2016, 31, 40-49. [CrossRef]

40. Shiwen, W.; Jing, R.; Ting, H.; Guanru, Q.; Haihui, H.; Wenhui, L.; Wu, F.; Kai, P. Evaluation of soil enzyme activities and microbial communities in tomato continuous cropping soil treated with jerusalem artichoke residues. Commun. Soil Sci. Plant Anal. 2018, 49, 2727-2740. [CrossRef]

41. Fudou, R.; Jojima, Y.; Iizuka, T.; Yamanaka, S. Haliangium ochraceum gen. nov., sp. nov. and Haliangium tepidum sp. nov.: Novel moderately halophilic myxobacteria isolated from coastal saline environments. J. Gen. Appl. Microbiol. 2002, 48, 109-115. [CrossRef] [PubMed]

42. Barron, G.L.; Morikawa, C.; Saikawa, M. New Cephaliophora species capturing rotifers and tardigrades. Can. J. Bot. 1990, 68, 685-690. [CrossRef]

43. Pavlou, G.; Vakalounakis, D. Biological control of root and stem rot of greenhouse cucumber, caused by Fusarium oxysporum $\mathrm{f}$. sp. radicis-cucumerinum, by lettuce soil amendment. Crop. Prot. 2005, 24, 135-140. [CrossRef]

44. Ogundeji, A.O.; Li, Y.; Liu, X.; Meng, L.; Sang, P.; Mu, Y.; Wu, H.; Ma, Z.; Hou, J.; Li, S. Eggplant by grafting enhanced with biochar recruits specific microbes for disease suppression of Verticillium wilt. Appl. Soil Ecol. 2021, 163, 103912. [CrossRef]

45. Ilić, Z.S.; Milenković, L.; Stanojević, L.; Cvetković, D.; Fallik, E. Effects of the modification of light intensity by color shade nets on yield and quality of tomato fruits. Sci. Hortic. 2012, 139, 90-95. [CrossRef]

46. Sun, W.; Qian, X.; Gu, J.; Wang, X.-J.; Duan, M.-L. Mechanism and Effect of Temperature on Variations in Antibiotic Resistance Genes during Anaerobic Digestion of Dairy Manure. Sci. Rep. 2016, 6, 30237. [CrossRef] [PubMed]

47. Yang, S.; Song, L. Succession of bacterial community structure and metabolic function during solid waste decomposition. Bioresour. Technol. 2019, 291, 121865. [CrossRef]

48. Bastian, F.; Bouziri, L.; Nicolardot, B.; Ranjard, L. Impact of wheat straw decomposition on successional patterns of soil microbial community structure. Soil Biol. Biochem. 2009, 41, 262-275. [CrossRef]

49. Wang, X.; Wu, H.; Dai, K.; Zhang, D.; Feng, Z.; Zhao, Q.; Wu, X.; Jin, K.; Cai, D.; Oenema, O.; et al. Tillage and crop residue effects on rainfed wheat and maize production in northern China. Field Crop. Res. 2012, 132, 106-116. [CrossRef] 
50. Xia, L.; Lam, S.K.; Wolf, B.; Kiese, R.; Chen, D.; Butterbach-Bahl, K. Trade-offs between soil carbon sequestration and reactive nitrogen losses under straw return in global agroecosystems. Glob. Chang. Biol. 2018, 24, 5919-5932. [CrossRef]

51. Cao, Y.; Gao, Y.; Li, J.; Tian, Y. Straw composts, gypsum and their mixtures enhance tomato yields under continuous saline water irrigation. Agric. Water Manag. 2019, 223, 105721. [CrossRef]

52. Sui, N.; Zhou, Z.; Yu, C.; Liu, R.; Yang, C.; Zhang, F.; Song, G.; Meng, Y. Yield and potassium use efficiency of cotton with wheat straw incorporation and potassium fertilization on soils with various conditions in the wheat-cotton rotation system. Field Crop. Res. 2015, 172, 132-144. [CrossRef]

53. Zhao, S.; He, P.; Qiu, S.; Jia, L.; Liu, M.; Jin, J.; Johnston, A.M. Long-term effects of potassium fertilization and straw return on soil potassium levels and crop yields in north-central China. Field Crop. Res. 2014, 169, 116-122. [CrossRef] 